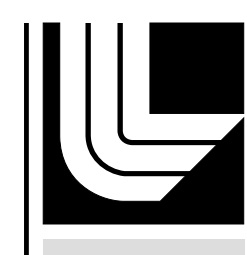

LAW RENCE LIVERMORE N A T IO N A L LABORATORY

NANOCRYSTALLINE GROWTH AND GRAIN-SIZE EFFECTS IN AU-CU ELECTRODEPOSITS

A. F. Jankowski, C. K. Saw, J. F. Harper, R. F. Vallier, J. L. Ferreira, J. P. Hayes

March 1, 2005

Thin Solid Films 
This document was prepared as an account of work sponsored by an agency of the United States Government. Neither the United States Government nor the University of California nor any of their employees, makes any warranty, express or implied, or assumes any legal liability or responsibility for the accuracy, completeness, or usefulness of any information, apparatus, product, or process disclosed, or represents that its use would not infringe privately owned rights. Reference herein to any specific commercial product, process, or service by trade name, trademark, manufacturer, or otherwise, does not necessarily constitute or imply its endorsement, recommendation, or favoring by the United States Government or the University of California. The views and opinions of authors expressed herein do not necessarily state or reflect those of the United States Government or the University of California, and shall not be used for advertising or product endorsement purposes. 


\title{
Nanocrystalline growth and grain-size effects in Au-Cu electrodeposits
}

\author{
Alan F. Jankowski*, Cheng K. Saw*, Jennifer F. Harper*, Bobby F. Vallier*, James L. \\ Ferreira*, and Jeffrey P. Hayes** \\ Lawrence Livermore National Laboratory \\ *Chemistry and Materials Science, Materials Science and Technology Division \\ **Engineering, New Technologies Engineering Division \\ P.O. Box 808, Livermore, CA 94550 U.S.A.
}

\begin{abstract}
The processing-structure-property relationship is investigated for electrodeposited foils of the gold-copper alloy system. A model is presented that relates the deposition process parameters to the nanocrystalline grain size. An activation energy of $1.52 \mathrm{eV} \cdot \mathrm{atom}^{-1}$ for growth is determined for a long pulse $(>10 \mathrm{msec})$ mode, and is $0.16 \mathrm{eV} \cdot$ atom $^{-1}$ for short pulses $(<5 \mathrm{msec})$. The affect of nanocrystalline grain size on the mechanical properties is assessed using indentation measurements. A Hall-Petch type variation of the Vickers microhardness with nanocrystalline grain size ( $>6 \mathrm{~nm})$ is observed for Au-Cu samples with 1-12 wt.\% Cu as tested in cross-section. The hardness increases three-fold from a rule-of-mixtures value $<1 \mathrm{GPa}$ to a maximum of $2.9 \mathrm{GPa}$.
\end{abstract}




\section{Introduction}

The technology of forming novel material coatings by electroplating, i.e. electrodeposition, has a variety of uses including wear resistant surfaces, protective barrier coatings, and structural applications.[1] At present, our motivation is to study the enhancement of strength in Au-Cu alloys through nanocrystalline grain size control. Synthesis of high-strength materials, i.e. $>500 \mathrm{MPa}$ flow stress, in the form of capsule coatings is considered an attractive option for use as a pressure vessel.[2] Au coatings of a few microns thick were successfully electrodeposited onto thin polymer shells to demonstrate this application. Our initial objective is to deposit 10-30 $\mu \mathrm{m}$ thick $\mathrm{Au}-\mathrm{Cu}$ foils having a composition of 1-12 wt.\% $\mathrm{Cu}$ to determine if nanocrystalline grain size refinement can appreciably harden the alloy.

The electrodeposition process has been used to produce both "soft" and "hard" Au coatings. [3-5] Nucleation and growth of "soft" Au from a citrate acid solution is descirbed in terms of two- and three-dimensional growth modes.[4] Acidic $(\mathrm{pH} \sim 5)$ cyanide and near-neutral ( $\mathrm{pH} \sim 7.4$ ) thiosulfate-sulfite electrolytes for "soft" Au plating at $\sim 60^{\circ} \mathrm{C}$ yield films with hardness values of 0.7-1.0 GPa.[6] "Hard" Au can be produced by codeposition with low quantities of metal hardeners as nickel, cobalt, or iron.[5, 7-9] In the present study, $\mathrm{Cu}$ will serve as the additive. Alkaline solutions from cyanide salts will be used for the electrodeposition of the Au-

$\mathrm{Cu}$ foils.[10-11] Hardness values up to $3.9 \mathrm{GPa}$ are reported for deposits prepared this way.[10]

\section{Experimental Synthesis}

Coatings are prepared through the aqueous process of plating metals from an ionic solution. An electric pulse up to $60 \mathrm{msec}$ in length (using a mode of current control) is passed 
through the electrolytic solution from the anode to the cathode surface where the metal coating forms. The actual current and voltage during the deposition are measured between the electrodes. The synthesis apparatus is comprised of the following basic components. The electrolytic solution is placed within a small polypropylene tank (with a $\sim 2$ liter capacity) wherein drynitrogen gas can be used to agitate and circulate the solution. The polypropylene tank is suspended within a heated water bath of a stainless steel tank. Convective heating of the water bath warms the metal-ion electrolytic solution to a temperature of $55-75^{\circ} \mathrm{C}$. For deposition of the $\mathrm{Au}-\mathrm{Cu}$ alloys, an anode of $7.5 \mathrm{~cm}$-wide Pt plate is separated by $2.54 \mathrm{~cm}$ from a cathode substrate sheet of titanium (or stainless steel). The $3 \mathrm{~cm}$-high by $4 \mathrm{~cm}$-wide coating is removed from the substrate by peeling. The electrodeposition is conducted using a No. 2 Au bath with a $\mathrm{pH} \sim 11$. A one-liter volume of the bath is comprised of de-ionized water with 6.4-8.0 gm KCN, 6.4-8.8 $\mathrm{gm} \mathrm{KCu}(\mathrm{CN})_{2}$, and 1.0-3.0 $\mathrm{gm} \mathrm{KAu}(\mathrm{CN})_{2}$.

\section{Characterization Results and Analysis}

The morphology and composition of the electrodeposited foil can vary with the cell potential $(U)$ as dependent on solute concentrations, the pulse length $\left(t_{p}\right)$, and current density $(j)$. The foil composition is determined by the atomic number-absorption-florescence (ZAF) semiquantitative analysis. The energy dispersive x-ray spectra of the electrodeposited foils reveal characteristic $\mathrm{Cu} L$ and $\mathrm{Au} M$ x-ray peaks that are used to quantify the composition. Details that correlate typical growth morphologies and surface features with deposition parameters will be reviewed in the discussion as pertinent to the control of grain size and foil composition. The surfaces of $10 \mu \mathrm{m}$ thick $\mathrm{Au}-\mathrm{Cu}$ foils are imaged using secondary electrons in a scanning electron microscope. The Fig. 1 images are representative of the $\mathrm{Au}-\mathrm{Cu}$ foils with 5-55 wt.\% Cu. Typical 
surface features can vary from smooth to nodular. Smoother surfaces that are found at long pulse lengths for a 35 wt.\% Cu sample prepared using a $50 \mathrm{msec}$ on-pulse (Fig 1a.) and for a 40 wt.\% Cu sample prepared using a 30 msec on-pulse (Fig 1b.) can coarsen at short pulse lengths with the appearance of nodular surface features in a $55 \mathrm{wt} . \% \mathrm{Cu}$ sample prepared using a $1 \mathrm{msec}$ onpulse (Fig 1c.). For Au-rich deposits (of Figs. 1d-f), the surfaces again vary from smooth to nodular. For $5 \mathrm{wt} . \% \mathrm{Cu}$ deposits, the smooth features found at a small current density of 2 $\mathrm{mA} \cdot \mathrm{cm}^{-2}$ (Fig. 1e) can coarsen to faceted-dendritic features with an increase in current density to $3 \mathrm{~mA} \cdot \mathrm{cm}^{-2}$ (Fig. 1d), and further yet to nodular features at $5 \mathrm{~mA} \cdot \mathrm{cm}^{-2}$ (Fig. 1f).

The as-deposited $\mathrm{Au}-5 \mathrm{wt} . \% \mathrm{Cu}$ foils have an equiaxed nanocrystalline structure as revealed by transmission electron microscopy using bright-field imaging in plan view (Fig. 2a) and selected-area diffraction (Fig. 2b). The crystallite size is quantified by analyzing peakbroadening of the Bragg reflections in the (Fig. 3) $\mathrm{Cu} k_{\alpha}$ X-ray diffraction scans taken in the $\theta / 2 \theta$ mode. The crystallite, i.e. grain, size $\left(\mathrm{d}_{\mathrm{g}}\right)$ is determined from the (111) reflections using the Debye-Scherrer formulation. The crystallite size $\left(\mathrm{d}_{\mathrm{g}}\right)$ is determined using the formulation,

$$
\mathrm{d}_{\mathrm{g}}=0.9 \cdot \lambda \cdot\left(\mathrm{B} \cdot \cos \Theta_{\mathrm{B}}\right)^{-1}
$$

where $\lambda$ is $\mathrm{x}$-ray wavelength, and $2 \Theta_{\mathrm{B}}$ is the position of the Bragg reflection. The corrected fullwidth (B) at half-maximum intensity of the Bragg reflection is determined by the formulation,

$$
\mathrm{B}^{2}=\mathrm{B}_{\mathrm{m}}^{2}-\mathrm{B}_{\mathrm{s}}^{2}
$$

where $B_{m}$ (in radians) is the full-width measured at half-maximum intensity, and $B_{s}$ is $0.19^{\circ}$ for a reference $\mathrm{Au}$ (111) single-crystal standard. The x-ray spectra (of Fig. 3) for the $13.1 \mathrm{~nm}$ and 17.2 $\mathrm{nm}$ grain size specimens contain all of the fundamental reflections with relative intensities that correlate with the standard, powder diffraction file (PDF no. 04-0784) for equiaxed polycrystalline $\mathrm{Au}$. There is no evidence for textured film growth in the diffraction scans. 
The variation of Vickers microhardness $\left(\mathrm{H}_{\mathrm{v}}\right)$ with the inverse-square root of grain size $\left(\mathrm{d}_{\mathrm{g}}\right)^{-0.5}$ is plotted (in Fig. 4) for Au-Cu samples measured in cross-section using a $5 \mathrm{gf}$ indent load. For these electrodeposited samples with 1 to $12 \mathrm{wt} . \% \mathrm{Cu}$, the $\mathrm{H}_{\mathrm{v}}$ increases from a rule-ofmixtures value of $0.8 \mathrm{GPa}$ to a maximum of $2.9 \mathrm{GPa}$ as the grain size decreases to $6 \mathrm{~nm}$. The single-line fit to this classic Hall-Petch variation, $\mathrm{H}_{\mathrm{v}} \alpha k \cdot \mathrm{d}_{\mathrm{g}}{ }^{-0.5}$, indicates that grain size (and not solid-solution chemistry) is the dominant factor for hardening in these foils. The material constant $k$, determined from the slope of the increase, is $6.5 \mathrm{GPa}^{-\mathrm{nm}^{0.5}}$. Below a nanocrystalline grain size of $\sim 6 \mathrm{~nm}$, it appears that hardening in $\mathrm{Au}-\mathrm{Cu}$ attributable to grain boundary pinning yields to a grain-boundary sliding mechanism [12] as $\mathrm{H}_{\mathrm{v}}$ may then decrease.

The deposition parameters of current density (with pulse length) and cell potential affect the grain size and composition of the foils. The grain size $\left(\mathrm{d}_{\mathrm{g}}\right)$ is observed (in Fig. 5) to decrease with an increase in the current density (j). Two curves can be distinguished based on the duration of the on-time for the current pulse $\left(t_{p}\right)$. A short pulse $\left(t_{p}<5 \mathrm{msec}\right)$ regime shows a faster decrease in $\mathrm{d}_{\mathrm{g}}$ with increasing $\mathrm{j}$ than does the long pulse $\left(10<\mathrm{t}_{\mathrm{p}}<30 \mathrm{msec}\right)$ regime. Also, we have found in electrodepositing $\mathrm{Au}-\mathrm{Cu}$ from cyanoalkaline-based solutions, as reported elsewhere [10-11], that a decrease in the current density and cell potential favor deposition of the more noble metal species. This result is observed in a (Fig. 6) plot of grain size $\left(\mathrm{d}_{\mathrm{g}}\right)$ versus the average $\mathrm{Au}$ composition $\left(\mathrm{c}_{\mathrm{Au}}\right)$ as a function of current density (j). The decrease in $\mathrm{c}_{\mathrm{Au}}$ with an increase in $\mathrm{j}$ is furthered when the cell potential (U) is increased, as seen in Fig. 6 for enveloping groups of data at $0.5-0.8 \mathrm{~V}, 0.8-1.0 \mathrm{~V}$, and 1.0-2.5 V. The decrease in $\mathrm{d}_{\mathrm{g}}$ with increase in $\mathrm{j}$ (seen in Fig. 5) is an effect of film composition. An increase in the $\mathrm{Cu}$ composition $\left(\mathrm{c}_{\mathrm{Cu}}\right)$ with an increase in $\mathrm{j}$ (seen in Fig. 6) appears to favors grain refinement as seen in Fig. 5. Also, the decrease in $\mathrm{c}_{\mathrm{Au}}$ with increasing $\mathrm{j}$ (in Fig. 6) is attributable to the mobility of $\mathrm{Au}$ ions versus $\mathrm{Cu}$ 
ions in solution. As $\mathrm{j}$ is increased, the mobility of $\mathrm{Cu}$ is increased and the effect is that the $\mathrm{Cu}$ composition is increased in the deposited coating.

\section{Electrodeposited Grain-Size Model}

The use of a pulsed-current is known to refine the grain size of the electrodeposited coatings.[13] Whereas grain growth is favored at a low cell potential with high surface diffusion, a high cell potential with low surface diffusion promotes nuclei formation. A pulsed current can facilitate nuclei formation as the peak current density can be considerably higher than the limiting direct-current density. We find (as seen in Fig. 5) that grain size at the nanoscale is refined for the $\mathrm{Au}-\mathrm{Cu}$ electrodeposits at greater current densities as the pulse duration $\left(\mathrm{t}_{\mathrm{p}}\right)$ is increased. This result may suggest a difference in the energetic barrier for stabilization of grain size between each pulse-duration mode. That is, the long pulse has an additional barrier to inhibit bulk-like diffusion whereas growth for the short pulse is primarily limited to the barriers for nucleation and surface diffusion. A difference in growth may then be apparent in the energetic barrier for grain formation. The long pulse mode should have an a barrier for grain formation $\left(\mathrm{Q}_{\mathrm{lp}}\right)$ that is greater than the energy for the short pulse mode $\left(\mathrm{Q}_{\mathrm{sp}}\right)$. Both $\mathrm{Q}_{\mathrm{sp}}$ and $\mathrm{Q}_{\mathrm{lp}}$ are likely to be less than the activation energy obtained from high-temperature, tracer-diffusion studies.

It's generally accepted that electrodeposited $\mathrm{Au}$, as from an acidic cyanide-based solution, proceeds through two different mechanisms.[14-17] At lower cell potentials, i.e. the more positive potential, deposition proceeds by an adsorption of AuCN followed by the electron transfer. At higher cell potential, i.e. the more negative potential, Au deposition occurs by direct charge-transfer reaction as

$$
\mathrm{Au}(\mathrm{CN})_{2}^{-}+2 \mathrm{H}^{+}+\mathrm{e}^{-} \rightarrow \mathrm{Au}+\mathrm{HCN}
$$


The adsorption of AuCN and the incorporation of impurities into Au deposits have an important affect on the nucleation and growth mechanism. For both "hard" and "soft" Au deposition from acidic cyanide solutions, inhibition of vertical crystal growth coincides with an increase in the negative cell potential.[4-5] However, it's likely that the adsorption of AuCN is not influenced by the $\mathrm{CN}^{-}$mass transfer when the concentration is high enough, as is the case for the alkaline cyanide solutions of this study.

A model is developed to determine the activation energy $(\mathrm{Q})$ for grain formation. The first premise is that a classic Arrhenius-type behavior for temperature-dependent diffusion in solids is assumed for the growth of electrodeposited coatings. That is, diffusion is mitigated by a negative exponential of the activation energy relative to the deposition energy. That is

$$
\mathrm{D}=\mathrm{D}_{\mathrm{o}} \cdot \mathrm{e}^{\left(-\mathrm{Q} / \mathrm{Q}^{*}\right)}
$$

where the coefficient D can be defined by the standard expression for ideal grain growth, as

$$
\partial \mathrm{D}=\partial\left(\mathrm{d}_{\mathrm{g}}^{2} \cdot \mathrm{t}_{\mathrm{p}}^{-1}\right)
$$

The activation energy (Q) in the exponent of eqn. (4) is divided by a term for the deposition energy $\left(Q^{*}\right)$ corresponding to the driving force for grain formation. Analogous to the solid solution, $\mathrm{Q}^{*}$ would be equivalent to the traditional equation-of-state expression $\left(\mathrm{k}_{\mathrm{B}} \cdot \mathrm{T}\right)$ where $\mathrm{k}_{\mathrm{B}}$ is the Boltzmann constant and $\mathrm{T}$ is the absolute temperature. For the electrodeposition process, Q* is equivalently defined from Faraday's Laws as the product of the cell potential (U) with the total charge $\left(q_{p}\right)$ in the number $(n)$ of deposited units (i.e. ions) during each current pulse. The general expression adopted for $\mathrm{Q}^{*}$ is

$$
\mathrm{Q}^{*}=\mathrm{N}_{\mathrm{A}} \cdot\left(\mathrm{q}_{\mathrm{p}} \cdot \mathrm{n}^{-1}\right) \cdot \mathrm{U}
$$

where $\mathrm{N}_{\mathrm{A}}$ is the Avogadro number $\left(6.023 \cdot 10^{23} \mathrm{~mol}^{-1}\right)$ and $\mathrm{q}_{\mathrm{p}}$ is assumed as equal to the product of the average current density (j) with the surface area (A) of the deposited unit with the duration of the pulse $\left(t_{p}\right)$. That is, an expression adopted for $q_{p}$ is 


$$
\mathrm{q}_{\mathrm{p}}=\mathrm{j} \cdot \mathrm{A} \cdot \mathrm{t}_{\mathrm{p}}
$$

For dense packing, of the deposited units, the area (A) can be equivalently approximated as the square of the grain size $\left(\mathrm{d}_{\mathrm{g}}{ }^{2}\right)$. For the electrodeposition of $\mathrm{Au}-\mathrm{Cu}$ from a high-pH alkaline solution described by eqn. 3 , singly charged ions are assumed accordingly. The number (n) of ions is then equivalent to the grain size area $\left(A=d_{g}{ }^{2}\right)$, divided by the area of a unit cell $\left(A_{o}\right)$. The unit cell area $\left(A_{o}\right)$ is equivalent to the square of the average $\mathrm{Au}-\mathrm{Cu}$ lattice parameter $\left(\mathrm{a}_{\mathrm{o}}\right)$, i.e. $\mathrm{A}_{o}$ $=\mathrm{a}_{\mathrm{o}}^{2}$. Thus, an expression for $\mathrm{n}$ is

$$
\mathrm{n}=\left(\mathrm{d}_{\mathrm{g}} \cdot \mathrm{a}_{\mathrm{o}}^{-1}\right)^{2}
$$

Equation (6) can now be rewritten using eqns. (9) and (10) as

$$
\mathrm{Q}^{*}=\mathrm{N}_{\mathrm{A}} \cdot\left(\mathrm{j} \cdot \mathrm{t}_{\mathrm{p}} \cdot \mathrm{a}_{\mathrm{o}}^{2}\right) \cdot \mathrm{U}
$$

Following eqn (4), a plot of $\left(\mathrm{Q}^{*}\right)^{-1}$ with $\ln \left[\partial\left(\mathrm{d}_{\mathrm{g}}{ }^{2} \cdot \mathrm{t}_{\mathrm{p}}{ }^{-1}\right)\right]$ should yield a straight line, the slope of which is equivalent to -Q. The short-pulse $\left(\mathrm{t}_{\mathrm{p}}<5 \mathrm{msec}\right)$ and long-pulse $\left(10<\mathrm{t}_{\mathrm{p}}<30 \mathrm{msec}\right)$ results obtained for the grain size measurements are plotted in Fig. 7. Two straight lines can be drawn in Fig. 7 corresponding to eqn. (4) yielding an activation energy (Q) for grain formation in the longpulse mode $\left(\mathrm{Q}_{\mathrm{lp}}\right)$ equal to $146 \mathrm{~kJ} \cdot \mathrm{mol}^{-1}\left(\right.$ i.e. $1.52 \mathrm{eV} \cdot$ atom $\left.^{-1}\right)$ and in the short-pulse mode $\left(\mathrm{Q}_{\mathrm{sp}}\right)$ equal to $15.2 \mathrm{~kJ} \cdot \mathrm{mol}^{-1}$ (i.e. $0.16 \mathrm{eV} \cdot$ atom $^{-1}$ ) with a $D_{0}$ value of $4 \times 10^{-12} \mathrm{~cm}^{2} \cdot \mathrm{sec}^{-1}$. As first evident in the Fig. 5 plot of grain size variation with current density, there are two regimes for nanocrystalline growth - a short and long pulse mode, each with a distinct activation energy.

\section{Discussion}

The various growth morphologies that appear in electrodeposits can be directly related to the electrolyte, additives, and the concurrent deposition process. For example, star-shaped Au crystallites are reported from a citrate bath of $\mathrm{KAu}(\mathrm{CN})_{2}$ containing an additive of benzyl dimethyl phenyl ammonium chloride.[18] The additive causes an electrochemical depolarization of 
the process resulting in a preferred (110) texture of crystallites with multiple twinning giving rise to a pentagonal symmetry. The growth of nanocrystalline $\mathrm{Au}-\mathrm{Cu}$ electrodeposits can start with a Au-rich region that changes in concentration with increasing thickness to equilibrate at an alloy composition.[19] Often, the $\mathrm{Au}-\mathrm{Cu}$ deposits can have a microstructure characterized of rounded crystal colonies (as seen in Figs. 1c and 1f) that are each several microns in size - a result of several nucleation events. Porosity can then occur at triple junctions. The results for the $\mathrm{Au}-\mathrm{Cu}$ surfaces shown in Fig. 1 infer that there is a range of current density and pulse to produce a smooth surface. Typically, smooth surfaces appear at a low current density (of $0.8-4 \mathrm{~mA} \cdot \mathrm{cm}^{-2}$ ), a short-to-intermediate pulse length (of $2-12 \mathrm{msec}$ ), and a low cell potential (of $0.53-0.71 \mathrm{~V}$ ). The present results are consistent with other reports, as e.g. in the review by Kohl [20], where a current density $<4 \mathrm{~mA} \cdot \mathrm{cm}^{-2}$ and a reaction potential of $0.6 \mathrm{~V}$ for alkaline solutions with a $\mathrm{pH}$ value greater than 9 to 10 produce smoother foils with a minimum of residual stress.

There appears to be a range of diffusion available in either the short-pulse or long-pulse mode to produce a smooth $\mathrm{Au}-\mathrm{Cu}$ surface (as shown in Fig. 1 e). With reference to the Fig.7 plot, a smooth surface results when $\ln D$, i.e. $\ln \left[\partial\left(\mathrm{d}_{\mathrm{g}}{ }^{2} \cdot \mathrm{t}_{\mathrm{p}}{ }^{-1}\right)\right]$, is greater than -22.0 for either the short- or long-pulse mode. The surface features roughen, i.e. become nodular, when $-22<\ln \mathrm{D}<-26$.

To form a nanocrystalline electrodeposited foil, the concept is to promote massive nucleation with reduced grain growth.[13, 21] The nanocrystalline grain size can be metastable as annealing above $150{ }^{\circ} \mathrm{C}$ is shown to yield exothermic reactions in differential scanning calorimetry traces that are associated with grain growth and ordering of the Au-Cu alloy.[19] The refinement of grain size to the nanoscale is shown to enhance the microhardness of electrodeposits in accordance with a Hall-Petch behavior.[13, 22-25] At some level of grain refinement, perhaps below $5-10 \mathrm{~nm}$, the flow stress and hardness are thought to decrease as a mechanism shift occurs from grain boundary strengthening to that of sliding.[12, 22-23] At present, a lower bound of $\sim 6 \mathrm{~nm}$ may appear for the present $\mathrm{Au}-\mathrm{Cu}$ electrodeposits. 
The composition and grain size of the $\mathrm{Au}-\mathrm{Cu}$ electrodeposits can be predictably determined from the deposition parameters as seen in Figs. 5 and 6, respectively. A correlation to the activation energy for grain growth in the long-pulse and short pulse modes is determined for the electrodeposition process as expressed in eqn (9) with a dependency on cell potential, current density and pulse length. The results are consistent with the dominant modes for growth. That is, the energy is greater for a long-pulse mode where surface and the bulk-equivalence of diffusion are present in addition to the nucleation dominated event for the short-pulse growth mode. In comparison, an activation energy $\left(\mathrm{Q}_{\mathrm{T}}\right)$ for grain growth of $1.85 \mathrm{eV} \cdot$ atom $^{-1}$ is reported for hightemperature tracer diffusion studies of both $\mathrm{Au}^{198}$ in $\mathrm{Cu}$ and $\mathrm{Au}^{198}$ in $\mathrm{Au}$.[26-27] As originally assumed, we find that $\mathrm{Q}_{\mathrm{sp}}<\mathrm{Q}_{\mathrm{lp}}<\mathrm{Q}_{\mathrm{T}}$.

\section{Summary}

The processing-structure-property relationship is investigated for gold-copper foils electrodeposited from cyanoalkaline solutions. The morphology and composition of the electrodeposited foil vary with the cell potential (U) as dependent on solute concentrations, the pulse length $\left(t_{p}\right)$, and current density $(\mathrm{j})$. The as-deposited $\mathrm{Au}-\mathrm{Cu}$ foils have an equiaxed nanocrystalline structure as revealed by transmission electron microscopy (in Fig. 2) as well as x-ray diffraction (in Fig. 3). The grain size $\left(d_{g}\right)$ is observed (in Fig. 5) to decrease with an increase in the current density $(j)$. A short pulse $\left(t_{p}<5 \mathrm{msec}\right)$ regime shows a faster decrease in $d_{g}$ with increasing $\mathrm{j}$ than does the long pulse $\left(10<\mathrm{t}_{\mathrm{p}}<30 \mathrm{msec}\right)$ regime. A decrease in $\mathrm{j}$ and $\mathrm{U}$ favor deposition of the more noble metal, i.e. Au (as seen in Fig. 6).

An empirical model is presented that relates the parameters of the electrodeposition process to the grain size of the growing foil. There are two regimes for nanocrystalline growth a short and long pulse mode, each with distinct activation energies. The long pulse has the 
additional contribution of bulk-like diffusion (with an activation energy of $1.52 \mathrm{eV} \cdot a^{-10 m}{ }^{-1}$ ) whereas the short pulse (with an activation energy of $0.16 \mathrm{eV} \cdot$ atom $^{-1}$ ) is limited to just surface diffusion and nucleation. For either condition, a transition in growth from a rough (or nodular) surface to a smooth surface results when $\ln \left[\partial\left(\mathrm{d}_{\mathrm{g}}{ }^{2} \cdot \mathrm{t}_{\mathrm{p}}{ }^{-1}\right)\right]$ exceeds a value of -22.0 (in Fig. 7).

The affect of nanocrystalline grain size on the mechanical properties is assessed using indentation measurements. A Hall-Petch variation of the Vickers microhardness with $d_{g}>6 \mathrm{~nm}$ is observed (in Fig. 4) for 1-12 wt.\% Cu samples as tested in cross-section. The single-line fit for

$\mathrm{H}_{\mathrm{v}} \alpha k \cdot \mathrm{dg}_{\mathrm{g}}^{-0.5}$ indicates that grain size (and not solid-solution chemistry) is the dominant factor for hardening. The material constant $k$ is $6.5 \mathrm{GPa}-\mathrm{nm}^{0.5}$ and $\mathrm{H}_{\mathrm{v}}$ increases to a maximum of $2.9 \mathrm{GPa}$.

\section{Acknowledgement}

This work was performed under the auspices of the U. S. Department of Energy by the University of California, Lawrence Livermore National Laboratory under Contract No. W-7405Eng-48. 


\section{References}

1. J.W. Dini, Electrodeposition: the materials science of coatings and substrates, Noyes Publications, Park Ridge, New Jersey, 1993

2. J.D. Illige, C.M. Yu, and S.A. Letts, J. Vac. Sci. Technol., 18 (1981) 1209

3. W. Chrzanowski, Y.G. Li, and A. Lasia, J. Applied Electrochemistry 26 (1996) 385

4. Y.G. Li, W. Chrzanowski, and A. Lasia, J. Applied Electrochemistry 26 (1996) 843

5. Y.G. Li and A. Lasia, J. Applied Electrochemistry 26 (1996) 853

6. M.J. Liew, S. Roy, and K. Scott, Green Chemistry 5 (2003) 376

7. W.T. Lee, Corros. Technol. 10 (1963) 4

8. L. Holt, R.J. Ellis, and J. Stanyer, Plating 60 (1973) 918

9. H. Angerer and N. Ibl, J. Applied Electrochem. 9 (1979) 219

10. B. Bozzini, G. Giovannelli, and P. Cavallotti, J. Appl. Electrochem. 29 (1999) 685

11. B. Bozzini and P.L. Cavalotti, J. Electrochem. Soc. 148 (2001) C231

12. T.G. Nieh and J. Wadsworth, Scripta Metall. Mater. 25 (1991) 955

13. U. Erb, G. Palumbo, R. Zugic, K.T. Aust, in C. Suryanarayana, J. Singh, F.H. Froes (eds.) Processing and Properties of Nanocrystalline Materials, The Minerals, Metals and Materials Society, Warrendale, Pennsylvania, 1996, p. 93

14. D.M. MacArthur, J. Electrochem. Soc. 119 (1972) 672

15. E.T. Eisenmann, J. Electrochem. Soc. 119 (1972) 717

16. M. Beltowska-Brezezinska, E. Dutkiewicz, and W. Lawicki, J. Electroanal. Chem. 99 (1979) 341

17. P. Bindra, D. Light, P. Freudenthal and D. Smith, J. Electrochem. Soc. 136 (1989) 3616

18. B. Bozzini, A. Faningliulo, and M. Serra, J. Crystal Growth 231 (2001) 589

19. L. Battezzati, M. Baricco, M. Belotti, and V. Brunella, Materials Science Forum 360-362 (2001) 253

20. P.A. Kohl, in M. Paunovic and M. Schlesinger (eds.) Fundamentals of Electrochemical Deposition, John Wiley Publishers, New York, 1999 
21. R.T.C. Choo, et al., J. Appl. Electrochem. 25 (1995) 382

22. R.W. Siegel, Mater. Sci. Forum 235-238 1997) 851

23. Y. Lu and P.K. Liaw, J Metals 53 (3) (2001) 31

24. J. Schiotz, F. Di Tolla, and K. Jacobsen, Nature 391 (1998) 561

25. F. Dalla Torre, H. Van Swygenhoven, and M. Victoria, Acta Materialia 50 (2002) 3957

26. A. Chatterjee and D.J. Fabian, Acta Metallurgica 17 (1969) 1141

27. H.M. Gilder and D. Lazarus, J. Phys. Chem. Solids 26 (1965) 2081 
Figures and Captions

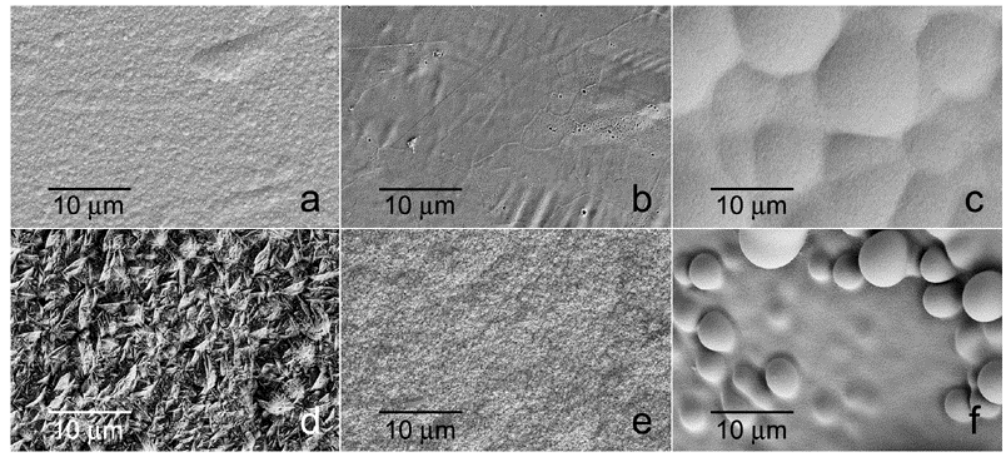

Figure 1. Scanning electron micrographs reveal the surface morphology of $\mathrm{Au}-\mathrm{Cu}$ electrodeposits for (a) a $35 \mathrm{wt} . \% \mathrm{Cu}$ sample prepared using a $50 \mathrm{msec}$ on-pulse, (b) a $40 \mathrm{wt} . \% \mathrm{Cu}$ sample prepared using a $30 \mathrm{msec}$ on-pulse, (c) a $55 \mathrm{wt} . \% \mathrm{Cu}$ sample prepared using a $1 \mathrm{msec}$ on-pulse, (d) a $5 \mathrm{wt} . \% \mathrm{Cu}$ sample prepared using a 3 $\mathrm{mA} \cdot \mathrm{cm}^{-2}$ current density, (e) a $5 \mathrm{wt} . \% \mathrm{Cu}$ sample prepared using a $2 \mathrm{~mA} \cdot \mathrm{cm}^{-2}$ current density, and (f) a $5 \mathrm{wt} . \% \mathrm{Cu}$ sample prepared using a $5 \mathrm{~mA} \cdot \mathrm{cm}^{-2}$ current density.
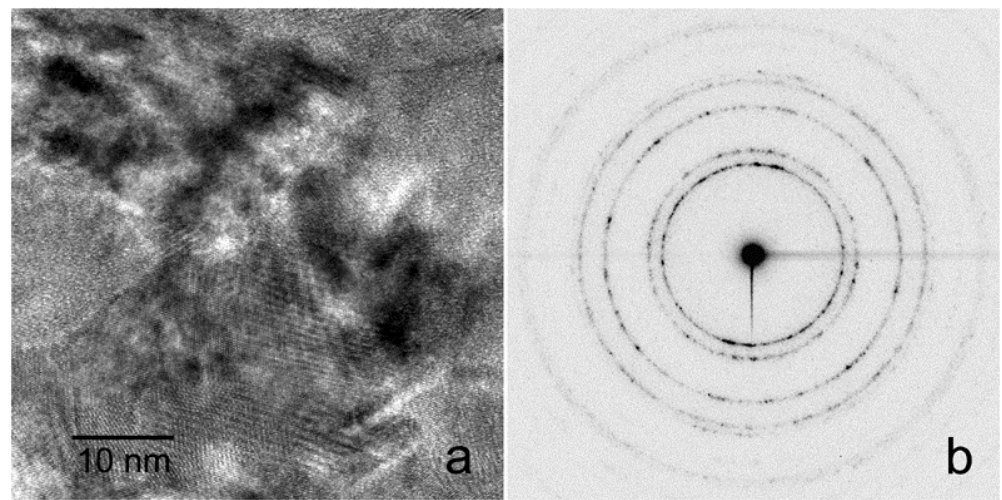

Figure 2. Transmission electron microscopy of a Au- $5 \mathrm{wt} . \% \mathrm{Cu}$ foil reveals (a) the nanocrystalline grain structure in of the high-resolution image, and (b) the equiaxed polycrystalline structure as present in the rings of the selected area diffraction pattern. 


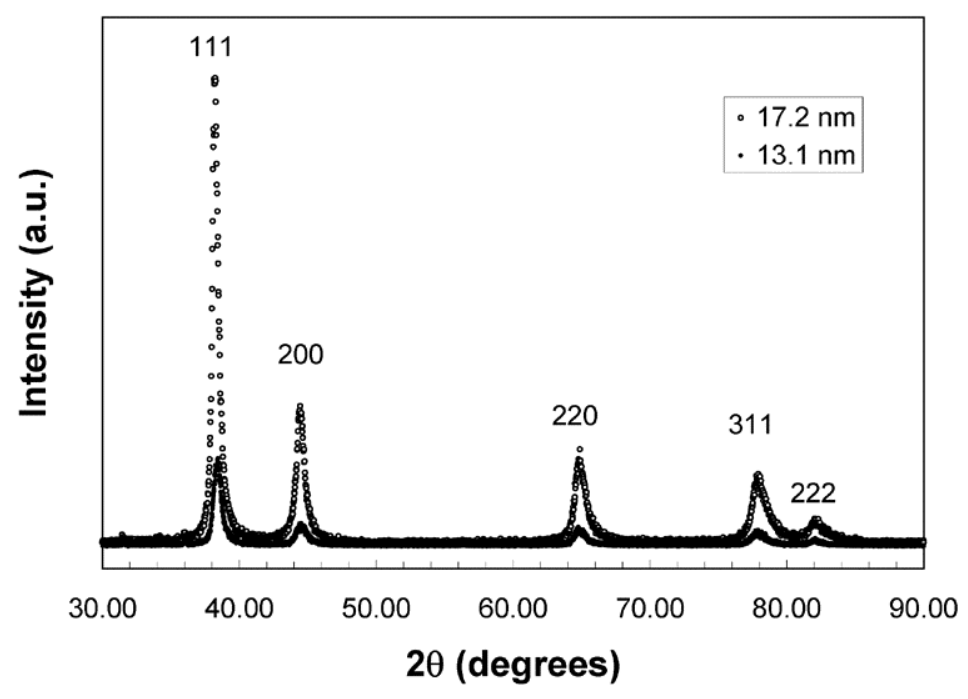

Figure 3. The $\mathrm{Cu} k \alpha$ diffraction scans, in the $\theta / 2 \theta$ mode, reveal peak broadening consistent with the nanocrystalline grain size variation of two equiaxed polycrystalline $\mathrm{Au}-5$ wt. $\% \mathrm{Cu}$ foils.

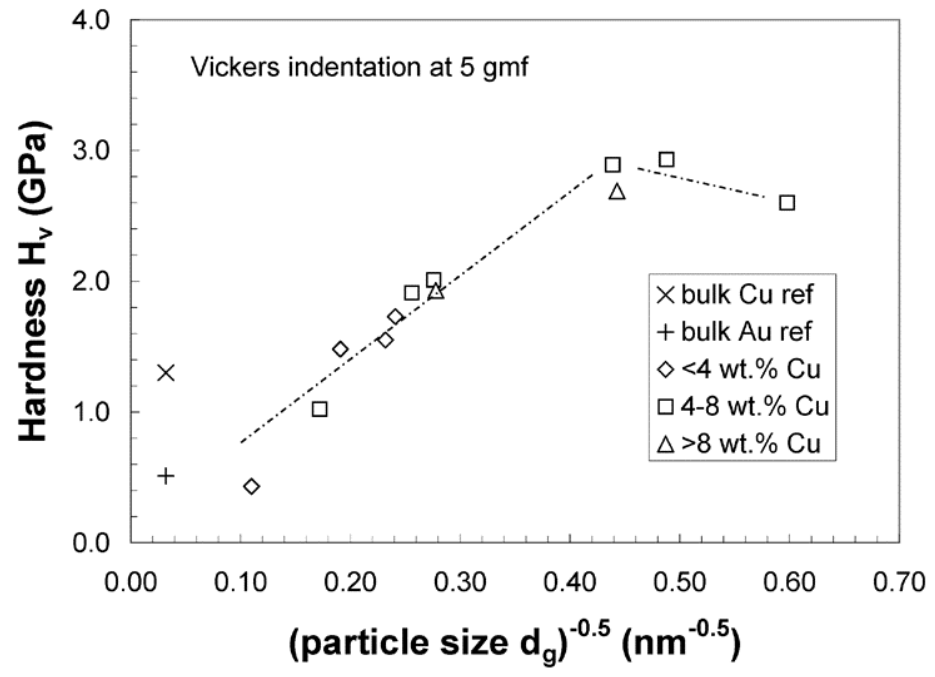

Figure 4. The Vickers microhardness $\mathrm{H}_{\mathrm{v}}(\mathrm{GPa})$ of the electrodeposited $\mathrm{Au}-\mathrm{Cu}$ foils is plotted versus the inverse-square root of grain size $d_{g}\left(\mathrm{~nm}^{-0.5}\right)$. 


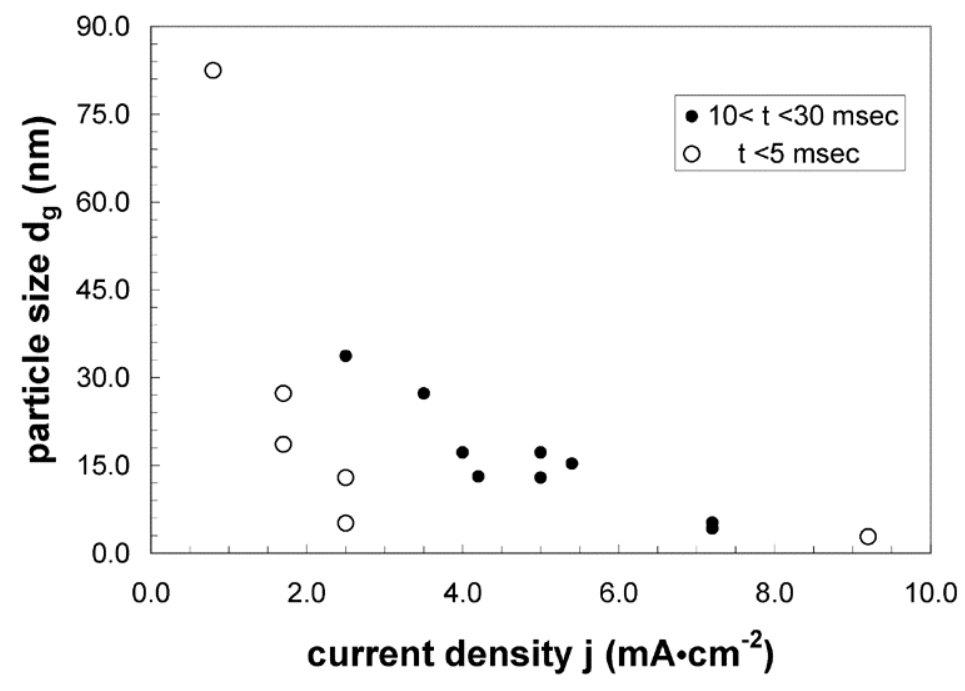

Figure 5. The average grain size $\mathrm{d}_{\mathrm{g}}(\mathrm{nm})$ of the electrodeposited $\mathrm{Au}-\mathrm{Cu}$ foils is plotted as a function of the current density $\mathrm{j}\left(\mathrm{mA} \cdot \mathrm{cm}^{-2}\right)$.

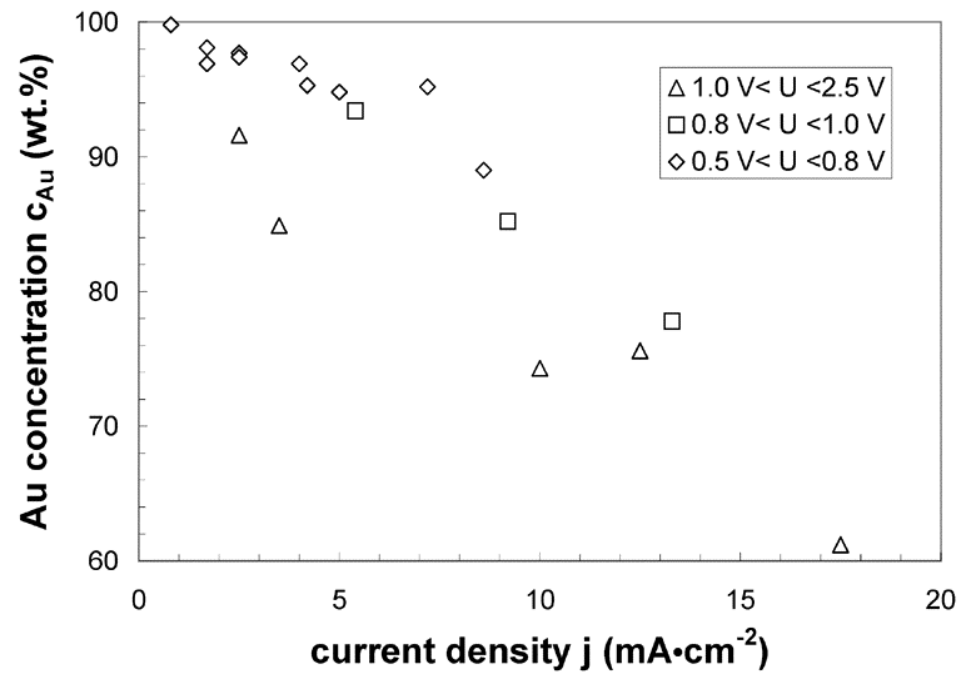

Figure 6. The average Au composition $\mathrm{c}_{\mathrm{Au}}(\mathrm{wt} . \%)$ through the thickness of the coating is plotted as a function of the current density $\mathrm{j}\left(\mathrm{mA} \cdot \mathrm{cm}^{-2}\right)$. 


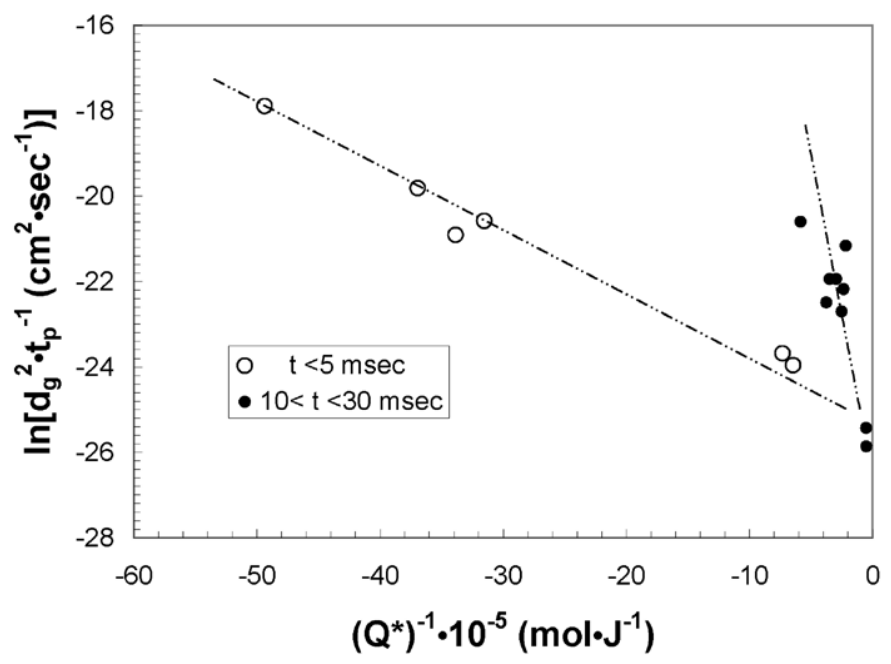

Figure 7. The natural logarithm of grain size $d_{g}$ squared, divided by the pulse duration $t_{p}$ yields an Arrhenius plot with the inverse of deposition energy $\mathrm{Q}^{*}\left(\mathrm{~mol} \cdot \mathrm{J}^{-1}\right)$. 